\title{
Howard P. Linton
}

$$
1912-1976
$$

Howard Linton, for many years connected with the library of Columbia University, first in charge of the East Asian collections and then (1962) as bibliographer in the School of International Affairs (he worked initially in the field of Russian and then in African studies), is especially remembered in the Association for Asian Studies for his labors on our first bibliographies. He was general editor of the Far Eastern Bibliograpby (1954-1955), and then of the much expanded Bibliograpby of Asian Studies (1956-1960).

In 1934 Howard graduated from Dartmouth College, where he majored in German, also studying Spanish and Italian. (He already had some competence in French.) He immediately found a place on the staff of the Dartmouth College library, serving there until 1942. During these years, he took the opportunity of studying Chinese with Professor David Lattimore (1937-38), and followed the intensive six weeks' seminar of the late George Kennedy in "advanced Chinese" at the University of Michigan (summer 1938). Next came several years at the Office of Strategic Services in Washington (September 1942-1947). Though busily engaged in war work, he studied Japanese under William Acker and later under Commander Ellsworth at George Washington University. He also pursued a course in "Everyday Russian" at the U.S. Department of Agriculture Graduate School. His appointment to the Columbia University Library followed in 1947. In addition to his work on Asian bibliography, Howard compiled for the Bio-Bibliographies Series of the School of International Affairs lists of the writings by and about McGeorge Bundy, Philip C. Jessup, Ralph J. Bunche, Paul G. Hoffman, Grayson L. Kirk, and Andrew W. Cordier.

He submitted his resignation to the University Library in 1973 , but continued to serve parttime until this last June. He passed away in mid-July at his apartment. A memorial service was held at St. John's chapel of Columbia University on August 7, attended by numerous friends and former colleagues. This quiet and unassuming man, with his gift for languages and for scholarly detail, will be greatly missed. Howard had one weakness; he loved dogs, and never neglected a chance to attend dog shows in this city. I liked that about him.

(I am indebted to Miss Miwa Kai of the East Asian Library for help in writing this memoir.)

Columbia University

L. Carrington Goodrich 